\title{
The current state of development of the meat products industry in Ukraine
}

\section{Introduction}

Modern meat processing factory is an open social and economic system. Its condition and development are strongly influenced by the environment, which is characterized with uncertainty, dynamism and unpredictability. Therefore, the problem of adapting the factories to the environmental changes gets particular importance and urgency. The degree of adequacy of economic behavior and enterprise management to the solutions of market requirements today are the critical factors in its successful long-term development. Considering the importance and key role of the meat and meat products market in increasing food security at the present stage, the study of this market will help to determine the underlying fundamentals of the necessary volume of meat and meat products and their market saturation in the required quantity and quality at the best price for their physical and price affordability for all sections of the population.

\section{Research objective and methodology}

The aim of the present research is to analyze the current situation, identify the main trends and problems of the meat market of Ukraine, identify the promising ways for its effective development and functioning. The materials for this research are the data of the State Statistics Committee of Ukraine, as well as scientific works of national authors, which examine status and dynamics of the meat industry. To identify and estimate trends of meat market functioning, the following research methods were used: statistical observation, grouping, analysis, synthesis, comparison, generalization and graphical method. 


\section{Research results}

Market of meat and meat products should be considered as one of the components of the agri-food market, in the structure of which there should be separately analyzed processes in the markets of beef, pork, sheep, goat and poultry meat. The essence of the market of meat and its products can be defined as an integrated, open organizational and economic system, which develops under the influence of factors of internal and external environment and consists of a set of enterprises involved in the production, processing, storage, transportation and sale [Nakai 2012]. Factors that contribute to quality improvement in the sector and ensure effective cooperation and development of all its elements, include stable connection between them, increasing mechanization level and work management of enterprises.

Meat industry should be considered as an integrated system that has its characteristic features of organization, structure, operation, such as [Bolshakov 1998]:

- $\quad$ satisfaction of the population demand for meat products;

- purposes of its functioning are determined by the basic economic and social objectives, first of all by meat and meat products release, and also by supplying other sectors of the economy with raw materials and semi-finished products;

- a structure that consists of several subsystems, the main feature of which is purposiveness determined by the general purpose of meat industry functioning;

- hierarchical construction where each element of an industry can be viewed as a system, and the industry is only one of the elements of the system of higher order;

- interaction with the environment, which should be understood in connection with both industries, companies, organizations, and with the natural systems.

Moreover, the following features of meat industry as a sector must be considered:

- the complexity of a system, branching links (meat processing companies interact with producers of raw materials, raw material suppliers, competitors, consumers, enterprises, which serve providers and manufacturers of meat products, etc.);

- significant dependence of enterprises' functioning on stable and effective mechanism of interaction of all the industry elements;

- high material consumption of the sector;

- significant vulnerability and dependence on imported raw materials; 
- high and constant level of risk in the meat industry, because on the one hand the market of sausages and meat delicacies depends on the supply of raw meat, and on the other hand meat products are perishable, and this feature has a certain effect on the nature of sales.

Development of meat processing enterprises is closely related to current situation with livestock farming industry. This industry must provide meat production in sufficient quantity, structure of range and adequate quality. Livestock is a capital intensive and highly risky sector of agriculture. Investment attractiveness of the industry, with the exception of poultry, is quite low due to the long production cycle and significant capital intensity. As a result, the number of livestock in the whole Ukraine constantly decreases, as Figure 1 shows. Namely, livestock production decreased from $4.49 \mathrm{~m}$ in 2010 to $3.75 \mathrm{~m}$ in 2015 , and production of cows - from $2.63 \mathrm{~m}$ to $2.16 \mathrm{~m}$. The number of pigs, sheep and goats also decreased from $7.96 \mathrm{~m}$ to $7.0 \mathrm{~m}$, from $1.73 \mathrm{~m}$ to $1.32 \mathrm{~m}$, respectively. The number of poultry increased, therefore, livestock of this type demonstrates dynamics of growth.

The national livestock first of all takes a responsible niche in ensuring of food security. Meat and meat products are the foundation of population wellbeing, and the rates of their consumption are one of the indicators of food security. The state and dynamics of the livestock industry influence not only economic

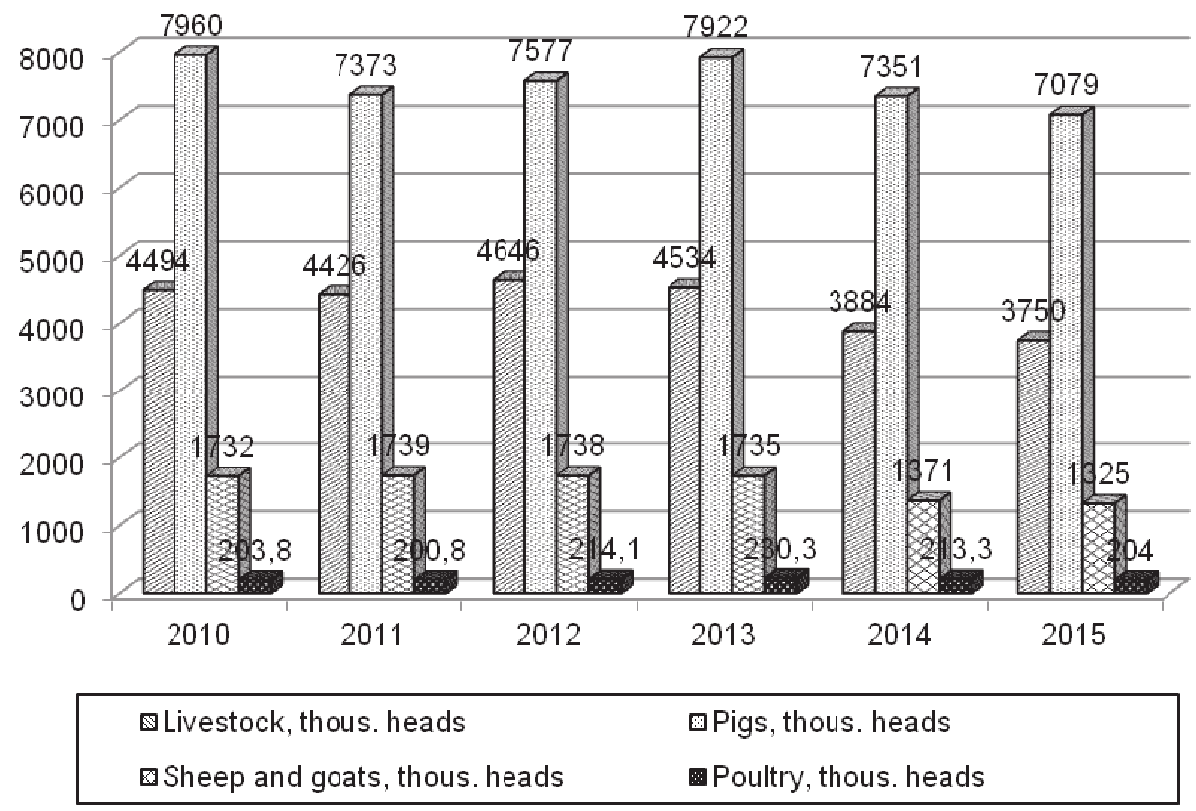

Figure 1

The number of animal heads in all categories of farms in 2010-2015

Source: Our processing based on State statistics service of Ukraine. 
indexes of agriculture but also quality of life level, wellbeing and food safety of the population [Information-analytical publication... ].

State and development of meat processing enterprises to some extent depend on the financial wellbeing and effective demand in the country. Economic growth and improving incomes contribute to increasing the consumption of meat products, and vice versa.

Analyzing the dynamics of food consumption in Ukraine, we note that at the optimum situation the indicator of consumption adequacy (the correlation between actual and reasonable consumption) should be equal to one - Table 1 . In 2015, in Ukraine in most major product groups the actual consumption was below the rational norms. As in previous years, the actual consumption of food in groups "potato" and "bakery products" exceeds the rational norm, which is an evidence of imbalance nutrition of population, which is trying to satisfy its energy needs by means of more affordable products. As for the consumption of meat and meat products (in terms of meat) per capita per year, the data indicate that in 2015 , compared to 2013, it decreased by $5 \mathrm{~kg}$. However, for the period from 2005 to 2015 the growth of consumption is evident. In 2015, compared with 2005 , consumption of meat and meat products increased by $12 \mathrm{~kg}$. The level of consumption of meat products to some extent affects the meat industry and dynamics of meat production.

As a result of a significant livestock reduction in all categories of farms, the meat production has decreased (Table 2). By 2015, fluctuations in domestic production of raw meat in slaughter weight of beef, pork, poultry, lamb, horse and rabbit were recorded. The growth of total meat production by Ukrainian manufacturers in 2013 was due to poultry and pork, while the volume of beef, mutton, horse and rabbit meat are falling.

We consider production of meat processing industry for the period from 2010 till 2015 (Table 3). According to the data of Table 3, a decline in production of all types of products is observed over the investigated period, which is a reflection of the economic crisis.

The problem of provision with commodity resources appears in the meat processing industry, for which the formation of raw capacity is an urgent task. The solution of this problem will help to create real prerequisites for improving the quantitative and qualitative indicators of the meat processing industry. The economic relations of meat industry are characterized by a fact that the value of meat products in agricultural production begins with the formation of fodder and growing livestock and ends by sale of finished products by trade enterprises. Economic relations in the chain "agricultural producers - processing enterprises - trade" exist in a dynamic sense, and therefore there is a need for continuous and 
Table 1

The dynamics of food consumption in Ukraine in selected years of period 2005-2015 in selected years of period [per capita per year]

\begin{tabular}{|c|c|c|c|c|c|c|c|c|c|}
\hline \multirow[b]{2}{*}{ Food groups } & \multirow{2}{*}{$\begin{array}{l}\text { Rational } \\
\text { norms of } \\
\text { food (cal- } \\
\text { culations } \\
\text { by MOH of } \\
\text { Ukraine) } \\
\end{array}$} & \multicolumn{7}{|c|}{ Actual consumption } & \multirow{2}{*}{$\begin{array}{c}\text { Indicator of consump- } \\
\text { tion adequacy in } 2015 \\
\text { (actual consumption } \\
\text { in } 2015 \text { to rational } \\
\text { norms) }\end{array}$} \\
\hline & & 2005 & 2010 & 2011 & 2012 & 2013 & 2014 & 2015 & \\
\hline $\begin{array}{l}\text { Meat and meat products (in } \\
\text { terms of meat, including fat and } \\
\text { offal in kind) [kg] }\end{array}$ & 80 & 39 & 52 & 51 & 54 & 56 & 54 & 51 & 0.63 \\
\hline $\begin{array}{l}\text { Milk and dairy products (in milk } \\
\text { equivalent) [kg] }\end{array}$ & 380 & 226 & 206 & 205 & 215 & 221 & 223 & 210 & 0.55 \\
\hline Eggs [pcs.] & 290 & 238 & 290 & 310 & 305 & 309.0 & 310 & 285.00 & 0.98 \\
\hline Fish and fish products [kg] & 20 & 14.40 & 14.50 & 13.40 & 13.60 & 14.60 & 11.10 & 9.00 & 0.45 \\
\hline Sugar [kg] & 38 & 38 & 37 & 39 & 38 & 37 & 36 & 36 & 0.94 \\
\hline Oil [kg] & 13 & 13.50 & 14.80 & 13.70 & 13.00 & 13.30 & 13.10 & 12.30 & 0.94 \\
\hline Potatoes [kg] & 124 & 136 & 129 & 139 & 140 & 135 & 141 & 138 & 1.11 \\
\hline $\begin{array}{l}\text { Vegetables and melons food } \\
\text { culture }[\mathrm{kg}]\end{array}$ & 161 & 120 & 144 & 163 & 163 & 163 & 163 & 161 & 1.00 \\
\hline $\begin{array}{l}\text { Fruits, berries and grapes } \\
\text { (excluding wine) }[\mathrm{kg}]\end{array}$ & 90 & 37 & 48 & 53 & 53 & 56 & 52 & 51 & 0.56 \\
\hline $\begin{array}{l}\text { Grain products (bread and pasta } \\
\text { in terms of flour, flour, cereals, } \\
\text { legumes) [kg] }\end{array}$ & 101 & 124 & 111 & 110 & 109 & 108 & 109 & 103 & 1.01 \\
\hline
\end{tabular}

Source: Our processing based on State statistics service of Ukraine. 


\section{4}

Table 2

Dynamics of meat production by types of carcass weight in 2010-2015 [thous. tons]

\begin{tabular}{|l|c|c|c|c|c|c|c|}
\hline $\begin{array}{l}\text { Meat production by types } \\
\text { (in slaughter weight) }\end{array}$ & 2010 & 2011 & 2012 & 2013 & 2014 & 2015 & $\begin{array}{c}2015 \\
\text { vs } \\
2010 \\
\text { [\%] }\end{array}$ \\
\hline Beef and veal & 428 & 399 & 388 & 428 & 413 & 384 & 89.7 \\
\hline Pork & 631 & 704 & 701 & 748 & 743 & 760 & 120.4 \\
\hline Lamb and goat meat & 21 & 20 & 20 & 19 & 14 & 14 & 66.6 \\
\hline Poultry meat & 954 & 995 & 1075 & 1168 & 1165 & 1144 & 119.9 \\
\hline Rabbit meat & 13 & 14 & 14 & 14 & 13 & 13 & 100.0 \\
\hline Horse meat & 12 & 12 & 12 & 12 & 12 & 8 & 66.6 \\
\hline Total & 2059 & 2144 & 2210 & 2389 & 2360 & 2323 & 112.8 \\
\hline
\end{tabular}

Source: Our processing based on State statistics service of Ukraine.

Table 3

Dynamics of production of meat processing industry in Ukraine in 2010-2015 [thous. tons]

\begin{tabular}{|l|c|c|c|c|c|c|c|}
\hline Production of the products & 2010 & 2011 & 2012 & 2013 & 2014 & 2015 & $\begin{array}{c}2015 \\
\text { vs } \\
2010 \\
{[\%]}\end{array}$ \\
\hline Sausage products & 281 & 292 & 294 & 294 & 267 & 236 & 84.0 \\
\hline $\begin{array}{l}\text { Ready products and } \\
\text { canned poultry meat }\end{array}$ & 3.2 & 2.6 & 2.4 & 2.7 & 2.8 & 2.5 & 78.1 \\
\hline $\begin{array}{l}\text { Ready products and } \\
\text { canned pork }\end{array}$ & 2.9 & 2.4 & 1.9 & 2 & 2.1 & 1.8 & 62.1 \\
\hline $\begin{array}{l}\text { Ready products and } \\
\text { canned beef and veal }\end{array}$ & 3.9 & 3 & 2.5 & 3.8 & 3.1 & 2.7 & 69.2 \\
\hline
\end{tabular}

Source: Our processing based on State statistics service of Ukraine.

comprehensive study in terms of agricultural, industrial and overall economic relations.

Inconsistency of development intensity of raw materials and processing industry has made a very real problem of raw material shortages - one of the factors contributing to the rapid increase in imports of meat and meat products in 2010-2016 respectively. Thus, in 2012 it reached a record value - 423 thous. tons.

During the years 2010-2016 the growing trend in sales of domestic meat products in foreign markets was observed. Whereas in 2010 there were exported 48 thous. tons of meat and meat products, in 2016 there were exported 302 thous. 
tons, that is $430 \%$ more. In the process of gradual increase of the volume of supplies from Ukraine, in 2014 exports of meat products for the first time over the investigated period exceeded imports for $8.5 \%$ (218 thous. tons against 201 thous. tons), which, in turn, shows gradual reduction of import dependency of our country in this area (Fig. 2).

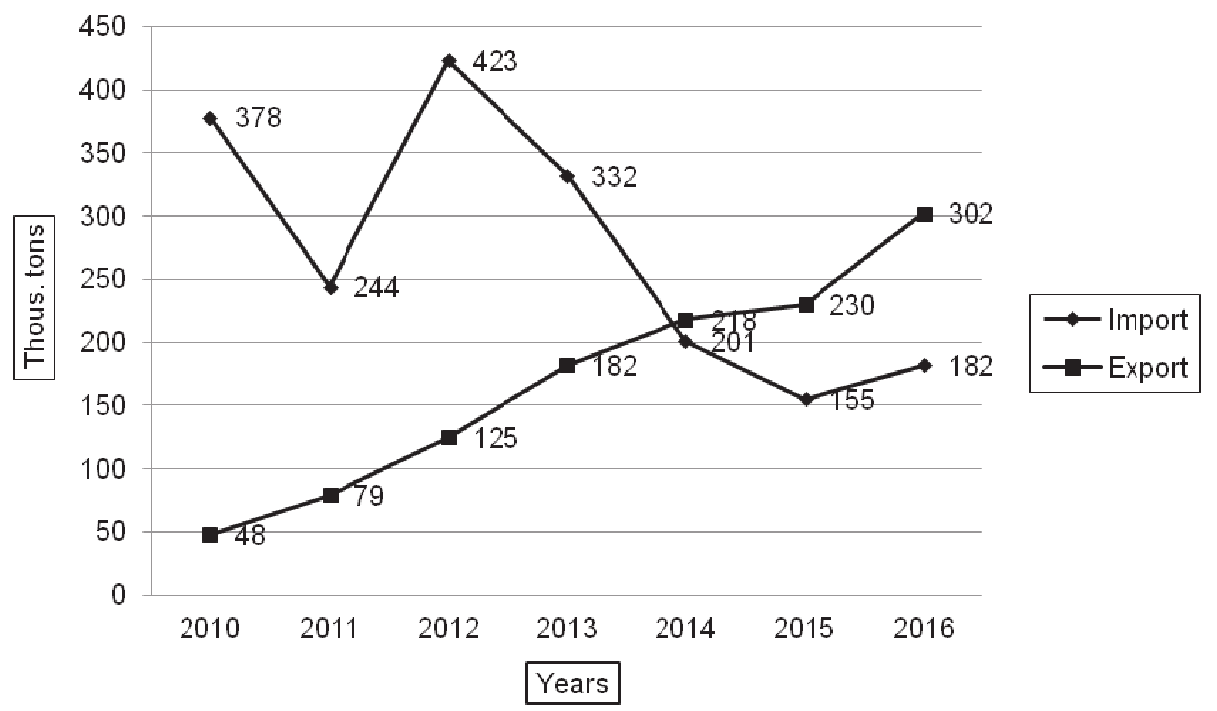

\section{Figure 2}

Dynamics of import and export of meat and meat products in 2010-2015

Source: Own processing based on State statistics service of Ukraine.

According to the data of Table 4, during the period from 2010 till 2016 the pork is the largest part of the imports. Thus, in 2010 the pork accounted for $51 \%$ (193 thous. tons in imported meat) and in 2016 for $47 \%$ (86 thous. tons). The second place was taken by poultry meat, but its part decreased over the investigated period. In 2010 there were imported 157 thous. tons of poultry meat, while in 2016 only 73 thous. tons. As for beef and veal, the tendency of decreasing their import is observed. In 2010 their import accounted for 25 thous. tons and in 2016 for 21 thous. tons.

As for the export volumes, their size for poultry constantly increases, in contrast to another kinds of meat. In 2010 the domestic meat producers exported 33 thous. tons of poultry meat, and in $2016-205$ thous. tons, that is six times more. This indicates the strategic importance of poultry in Ukraine. During 2010-2011 the country exported annualy 13 thous. tons of beef and veal, but thier volume gradually increased and in 2016 it amounted to 37 thous. tons. The export volume 
Table 4

The composition, dynamics and structure of meat import and export for the years 2010-2016 [thous. tons]

\begin{tabular}{|l|c|c|c|c|c|c|c|}
\hline Indexes & 2010 & 2011 & 2012 & 2013 & 2014 & 2015 & 2016 \\
\hline All import, incl. & 378 & 244 & 423 & 332 & 201 & 155 & 182 \\
\hline Beef and veal & 25 & 23 & 16 & 19 & 7 & 16 & 21 \\
\hline Pork & 193 & 153 & 289 & 234 & 125 & 75 & 86 \\
\hline Poultry meat & 157 & 65 & 116 & 74 & 65 & 61 & 73 \\
\hline Other kinds of meat & 3 & 3 & 2 & 5 & 4 & 3 & 2 \\
\hline All export, incl. & 48 & 79 & 125 & 182 & 218 & 230 & 302 \\
\hline Beef and veal & 13 & 13 & 17 & 27 & 27 & 31 & 37 \\
\hline Pork & 1 & 14 & 25 & 8 & 15 & 37 & 59 \\
\hline Poultry meat & 33 & 50 & 82 & 146 & 176 & 161 & 205 \\
\hline Other kinds of meat & 1 & 2 & 1 & 1 & 0 & 1 & 1 \\
\hline
\end{tabular}

Source: Own processing based on State statistics service of Ukraine.

of the pork, over the period from 2010 till 2016 increased by 59 times. However, other kinds of meat were not exported in 2014 at all.

Further increase of meat exports will allow Ukrainian producers to enter new foreign markets, attract foreign investment, improve the competitiveness of domestic meat processing enterprises and strengthen the economy of Ukraine. The main countries to which Ukrainian meat is exported are Russia, Belarus, Kazakhstan, Moldova, Iraq. The main beef importers are the USA, Australia and Brazil; pork - Brazil, Poland, Germany; poultry - the USA, the Netherlands, Poland, Germany [Ukrainian independent information agency of news].

In the course of 2011-2016 the trend in price increase for livestock products was observed. Average sale prices for livestock and poultry in Ukraine in 2015 increased by $78 \%$ compared to 2010 , and by $44 \%$ compared to 2014 [Business...].

However, price increase still does not cover the rising costs of production and sale, because the meat market remains unbalanced. The increasing livestock production, including pork, is very important in the context of the state food policy. According to the experience of the developed countries, agricultural producers should be supported by law, by settling the financial, economic and organizational rules of the meat market, including the establishment of mechanisms of government management.

Thus, the price situation is quite unstable and it needs some regulation, including the state one. State regulation involves direct interference of public authorities in commodity exchange transactions, financial support to farmers, developing regulations and product quality standards, and monitoring their compliance. 
According to analytical studies of information company "Delo", industry leaders are grouped primarily by type of product, the second level of segmentation - in terms of production. The first and largest segment is "chicken". Two major players - "Nasha Ryaba" (Myronivska and Vinnitsa poultry farms) and "Agromars" - work across Ukraine and conduct the most active marketing activity. Revenue of the biggest factories "Myronivsky bakeries" in 2015 amounted to 9.5 bn UAH. Net revenue of "Agromars" (TM Gavrilovsky chickens) was 2.4 bn UAH. Following are the companies "Chornobaivske" and "Agricultural firm AVIS". Other manufacturers produced much less meat and they work mainly with neighboring regions [Business...].

In the pork segment also there is an absolute leader. The APK-Invest company, based near Krasnoarmyysk of Donetsk region, in which the number of pigs approximates to 22 thous. The following is a group of three companies with quantity of livestock within 12-12.7 thous. These are "SPE Globinskiy pig farm" (Poltava region), "Danosha" (Ivano-Frankivsk region) and "Agroprodservice" (Ternopil region). Besides them the major pork producers are "AK Slobozhansky", Ukrainian-British company "Niva Pereyaslavshchyny" (TM Pyatachok) and "Bahmutskiy Agrarian Union" (Amvrosiyivka, Donetsk region, TM "Schurui kym").

The segment of the largest producers of beef includes "Kozyatyn meat", "Konotop meat", "Meat factory YATRAN (Kirovograd)" and "Zhytomyr meat factory".

To increase the production of meat and processed meat products, meatprocessing enterprises are reconstructed and put into operation. There is ongoing technical equipping of meat processing industry with modern technological equipment, new appliances, comprehensively mechanized and automated production processes. Computer technologies become more widespread. Improvement of equipment allows to increase the processing properties of the raw material and the quality of the finished product. These solutions allow to discover new ways to survive in the competition of enterprises in the meat industry and increase the cost-effectiveness of their activities.

Ukraine has all the necessary conditions for expanding the production of quality meat products. These include: favorable climatic conditions, previous experience of great trade meat production, recovery of processing industries and increasing demand for raw materials. Besides, increased purchasing power and increased demand in the retail market for meat and finished products made of it. Rapid development of retail chains, improvement of channel sales, availability of skilled and relatively cheap labor are beneficial in large-scale meat production.

The priority directions of the industry development are: 
- expansion and improvement of harvesting and feeding networks and relations between producers and processors, increased purchases of livestock in private and state-owned farms;

- reconstruction and modernization of existing enterprises;

- development and creation of a modern efficient equipment for primary processing of livestock and meat; filling, packaging machinery; refrigeration and power equipment and so on;

- development of vertical and horizontal integration as a direction of formation the economically equitable relationships between participants of the process of production, processing and sale of meat and its products;

- creation of favorable conditions for investment activity - supporting medium and long-term commercial loans, implementation of investment projects and programs, including public support.

An important part of food policy in Ukraine at the present stage is to create a market of agricultural products and processed products, that provides population with balanced food, and gradual approximation of consumption of meat and meat products to rational standards.

\section{Conclusion}

Study of the current situation on the market of meat and meat products makes it possible to draw conclusions about the prospects of the industry. The development of Ukrainian meat processing enterprises in modern conditions is closely linked with the state of livestock production and meat industry. Supplying enterprises with raw materials in meat industry is an urgent task. Therefore, agricultural producers must be supported at the legislative level, by resolution of financial, economic and organizational aspects of the meat market, including establishment of balanced mechanisms for state governance of this market.

Inconsistency of consumption of meat and meat products per capita in Ukraine with existing standards confirms current capacity of the market of these products - and this is the prospect for the development of meat processing enterprises. Successful development of meat processing enterprises primarily requires dependable suppliers of raw materials, which will ensure their quality and safety. So the most advantageous form of organization of production is an agro-industrial integration of the most possible closed production.

During the studied period from 2010 to 2016 there was a positive trend of increasing export of domestic products over imports. For Ukraine it is important to increase the export of meat and meat products, because it will allow domestic 
producers to expand selling markets and increase profits. It should be noted that Ukraine has all the necessary conditions for the development of meat processing enterprises and growth of production of quality meat products.

Practical implementation of recommendations given in the article will allow the meat industry enterprises not only to effectively use their own production capacity, but also to maintain their positions in the relevant market or expand its certain sectors by means of a constant search and implementation of identified reserves in terms of resources and influence of external competitive environment factors.

\section{References}

BOLSHAKOV E., 1998: Scientific and engineering support of the meat industry: problem-system analysis, Food industry, Moscow.

Business Information-News Site, available at: https://delo.ua/.

Information-analytical publication “Agribusiness Today”, available at: http://www.agro-business.com.ua.

KOLYADA A., 2016: Analysis of the current state of the meat industry Ukraine, Statistic of Ukraine 1.

NAKAI O., 2012: Current state and problems of the meat market in Ukraine, Collected Works, Economic science, PVNZ Bukovina University, Books 218.

ONOPRIYENKO I., 2016: The formation of regional meat market, Global and National Economic Problems 10, 605-608.

ROMANISHYN O., 2013: Features of formation of meat market in Ukraine, Innovative Economy 46(8), 233-237.

SOLOMCHUK L., 2015: Current state of raw materials and market of meat in Ukraine, Scientific Works of NUFT 21(2), 78-85.

State Statistics Service of Ukraine, available at: http // - www.ukrstat.gov.ua.

Ukrainian Independent Information Agency of News, available at: https://economics.unian.ua.

\section{Abstract}

The aim of the present article is to analyze the current state of the market of meat and meat products in Ukraine to identify major problems with consideration of the industry specifics. The priority task was to provide recommendations for the development of the industry. The main features of meat production were identified in order to determine the main problems of the industry, namely the complexity of the system and branching connections, significant dependence of business stability and effectiveness on the efficiency of interaction of elements, high material consumption of the sector, vulnerability and high dependence on imported raw materials, as well as high and constant level of risk in the industry. 
Due to significant reduction in the number of animals of all categories, meat production also reduced. Over the period from 2010 to 2015, there were fluctuations in domestic production of raw meat. Ukrainian producers increased the total production of meat by poultry and pork, while reduced the volumes of beef production, since the low investment attractiveness of this industry due to the long production cycle and significant capital intensity. Based on the conducted study, there should be indicated growth factors regarding the meat industry: government support, increasing market price of raw meat and meat products, the use of resource-saving and modern technologies etc.

Food security involves governmental provision of appropriate food products that meet the needs of the population for quality nutrition and thier availability for each member of society. The consumption of meat and meat products in Ukraine does not satisfy the national standards rational standards. Consumption of meat products to some extent affects the meat industry, and the dynamics of production of meat. There is a general trend towards reducing the production of meat processing industry in Ukraine. Regarding the volume of exports by domestic producers, there is a gradual increase compared with imports, indicating a decrease of Ukraine's dependence on imports. As a result of the study, there were given guidelines on the development of the whole industry, which would help enterprises of the meat industry to develop effectively in the existing market.

Key words: market of meat and meat products, meat processing industry enterprises

\title{
Obecny stan rozwoju branży mięsnej na Ukrainie
}

\begin{abstract}
Abstrakt
Celem niniejszego artykułu jest przeprowadzenie analizy obecnego stanu rynku mięsa i wyrobów mięsnych na Ukrainie dla zidentyfikowania głównych problemów z uwzględnieniem osobliwości branży. Podstawowym zadaniem było udzielenie rekomendacji na temat rozwoju działalności branży. W artykule wyróżniono główne cechy branży mięsnej, które są istotą jej problemów, a mianowicie: skomplikowany system z wieloma powiązaniami, bardzo duża zależność efektywności działalności od stabilności i efektywności współdziałania elementów, duża wrażliwość na zależność od importowanego surowca, wysoki i stały poziom ryzyka w branży. Wskutek istotnego zmniejszenia pogłowia zwierząt we wszystkich kategoriach gospodarstw zmniejszyła się produkcja mięsa. W badanym okresie (2010-2015) odnotowano wahania krajowej produkcji su-
\end{abstract}


rowca mięsnego w wadze ubojowej. Ukraińscy producenci zwiększają całkowitą produkcję mięsa za sprawą mięsa drobiowego i wieprzowiny, a zmniejszają produkcję wołowiny, ponieważ atrakcyjność inwestycyjna tej branży jest dosyć mała ze względu na długi cykl produkcyjny oraz znaczną kapitałochłonność. Na podstawie badań należy wskazać czynniki rozwoju branży mięsnej: wsparcie państwowe, podwyższenie cen na rynku mięsa i zwiększenie produkcji mięsa, wykorzystanie nowoczesnych i surowcowo-oszczędnych technologii itd. Bezpieczeństwo żywnościowe polega na zabezpieczeniu przez państwo odpowiedniej liczby pełnowartościowych artykułów żywnościowych zaspokajającym zapotrzebowanie ludności oraz dostępnych dla każdego członka społeczeństwa. Badanie wykazało, że spożycie mięsa i jego przetworów na Ukrainie nie odpowiada poziomowi racjonalnej normy. Poziom konsumpcji produktów mięsnych w pewnej mierze wpływa na branżę mięsną i dynamikę produkcji wyrobów mięsnych, ponieważ na ogół obserwuje się tendencję do zmniejszenia produkcji w branży przetwórstwa mięsnego. W przypadku analizy wielkości eksportu produktów krajowych obserwuje się jego stopniowy wzrost w porównaniu z importem, co świadczy o spadku zależności importowej Ukrainy. Na podstawie wyników badań zaproponowano rekomendacje odnośnie rozwoju całej branży, które pomogą przedsiębiorstwom branży mięsnej efektywnie rozwijać się na istniejącym rynku.

Słowa kluczowe: rynek mięsa i wyrobów mięsnych, branża przetwórstwa mięsnego, przedsiębiorstwa 